\title{
Peningkatan Layanan Publik dan Biaya Operasional Perkantoran KUA: Sejarah, Pengelolaan dan Implikasi Terhadap Layanan KUA
}

\section{The Improvement of Public Services and Operational Costs of KUA Services: History, Management and Implications for KUA Services}

\author{
Angga Marzuki \\ Rumah Moderasi Islam (RUMI) \\ email: anggamarzuki@gmail.com \\ Artikel diterima 31 Maret 2020, diseleksi 20 Mei 2020, \\ dan disetujui 5 Juli 2020
}

Abstrak: Artikel ini menyajikan hasil kajian mengenai implikasi Biaya Operasinal (BOP) Kantor Urusan Agama (KUA) Kecamatan, BOP merupakan upaya Kementerian Agama untuk meningkatkan pelayanan KUA bagi masyarakat. Kajian ini bertujuan mencari tahu dan menguji bagaimana sebuah pendanaan layanan berimplikasi terhadap pelayanan publik. Penelitian ini menggunakan metodelogi penelitian kualitatif dengan rancangan studi kasus di sebuah KUA sebagai sampel. Hasil kajian ini, menyimpulkan bahwa BOP KUA sangat berperan dalam menggerakan program-program KUA, walaupun belum memenuhi semua Tugas Pokok dan fungsi KUA.Selain itu ditemukan bahwa adanya pengelolaan BOP masih dikontrol oleh Kantor Kementerian Agama Kabupaten, sehingga fungsi 9 layanan KUA tidak dapat dijalankan oleh para petugas di KUA. Padahal seyogyanya pihak KUA Kecamatan lah yang mempunyai wewenang secara penuh dalam penggunaan dan pengelolaan BOP KUA.

Kata Kunci: KUA, BOP, Pelayanan Publik 
Abstract: This article presents the study results of the Operational Costs (BOP) of the District Office of Religious Affairs (KUA)implications, BOP is an effort of the Ministry of Religion to support the improvement of KUA services for the society. This study aims to find out and test how the services funding has implications for public services. This study uses a qualitative research methodology with a case study design in a KUA as a sample.The results of this study concluded that the KUA BOP has very important role in moving the KUA programs, even though they have not fulfilled all the KUA main tasks and functions. In addition it was found that BOP management is still controlled by the District Ministry of Religion Office, so that the $9 \mathrm{KUA}$ services function cannot be carried out by KUA officers. Even though the Subdistrict KUA should have full authority in the use and management of BOP.

Keywords: Kantor Urusan Agama, Management, Public Service

\section{A. Pendahuluan}

Pelayanan publik merupakan dasar dan bentuk aktualisasi dari eksistensi birokrasi pemerintahan. Wajah birokrasi dapat tercermin dari sikap dan perilaku petugas dalam memberikan pelayanan kepada masyarakat. Bergesernya paradigma pelayanan yang lebih berorientasikepada pelanggan/masyarakat hendaknya dijadikan nilai yang melekat dalam jiwa aparatur pemerintah dan tercermin melalui sikap dan perilaku aparat dalam memberikan pelayanan kepada masyarakat. Inilah pelayanan publik yang ideal, yang seyogyanya diwujudkan oleh setiap insan pemberi pelayanan publik,karena bagaimana pun sebagai pemberi layanan publik harus mempunyai orientasi untuk memberikan kepuasan masyarakat sebagai penggunaa jasa dari layanan.

Layanan publikmau tidakmauharusmengikutizaman, pengembangan pembaruan layanan selalu berjalan dinamis, maka dari itu upaya untuk mengembangkan dan menghadirkan pelayanan yang prima seyogyanya 
selalu diusahakan oleh setiap insan pemberi layanan, setiap bentuk upaya dalam mengusahakan pelayanan yang akurat dan tepat sasaran selalu menjadi fokus di setiap periode pemerintahan, untuk konteks Indonesia, pergantian pejabat dan pemerintahan pusat, mereka selalu menerima estafet tongkat dalam memajukan pelayanan publik. Karena bagaimana pun, kehadiran negara bertujuan untuk mengorganisasikan pelayanan guna memenuhi kebutuhan masyarakatnya. Oleh karena itu, negara berkewajiban untuk menopang kebutuhan dasar untuk menjadi modal dalam memberikan dan menghadirkan pelayanan yang prima, itu juga yang melatar belakangi hadirnya dana dari Pemerintah pusat untuk pelaksana teknis dalam memberikan layanan, Biaya Operasional Perkantoran (BOP) yang di terima oleh setiap Kantor Urusan Agama Kecamatan adalah salah satu dana yang menjadi modal yang bersumber dari Pemerintah pusat untuk menjadi modal dalam memberikan pelayanan KUA Kecamatan.

KUA Kecamatan sebagai Unit Pelaksanan Teknis (UPT) dari Kementerian Agama sebagai unit yang memberikan pelayanan langsung kepada masyarakat.

Negara Indonesia memiliki daerah yang sedang giat dalam melakukan pembangunan yang dilaksanakan mulai dari pusat sampai ke daerah. Pembangunan di Indonesia saat ini tidak hanya diarahkan kepada tercapainya hasil fisik dan kesejahteraan materil, akan tetapi mencakup segala bidang yang lazimnya disebut dengan pembangunan nasional. Pembangunan nasional hanya akan berhasil dengan baik apabila diimbangi administrasi pemerintahan yang berdaya guna dan berhasil guna (efisien dan efektif) dalam melaksanakan yang bersifat pembangunan.

Uraian di atas menggambarkan bagaimana Negara berusaha secara terus menerus berupaya untuk memberikan pelayanan publik yang lebih baik lagi dengan memberikan dukungan sistem dan menggelontorkan anggaran yang berasal dari APBN, adapun kajian ini hendak menguji 
bagaimana implikasi dari Biaya Operasional Perkantoran (BOP) Kantor Urusan Agama (KUA) Kecamatan terhadap pelayanan publik yang ada di KUA, selain itu bagaimana pengelolaan BOP yang dilakukan oleh KUA dan dibandingkan atau disesuaikan dengan Keputusan Direktur Jenderal Bimbingan Masyarakat Islam Nomor 283 Tahun 2019 Tentang Petunjuk Pelaksanaan Pengelolaan Biaya Operasional Kantor Urusan Agama Kecamatan.

Penelitian ini dilakukan dengan menggunakan metode kualitatif. Sebagaimana disebut oleh Burhan Bungin, penelitian dengan menggunakan metode ini mengandalkan wawancara mendalam dan observasi, wawancara mendalam dilakukan pada kepala KUA, pegawai KUA yang membidangi pengelolaan BOP. Pada penelitian ini digunakan pendekatan administrasi pelayanan publik dan komparatif, dengan membandingkan bagaimana pengelolaan yang dilaksanakan oleh aparatur KUA dengan Kepdirjen Bimas Islam Nomor 23 Tahun 2019. pendekatan ini diyakini relevan untuk mendapatkan hasil analisa dari objek locus penelitian dan untuk mencari tahu sejauh mana implikasi dari Biaya Operasional Perkantoran (BOP) KUA Kecamtan dan kesesuaian peraturan yang dibuat pemerintah, dalam hal ini Kementerian Agama RI, yang dilaksanakan oleh Direktorat Jenderal Bimas Islam, dengan implementasi pengelolaan BOP.

Metode random digunakan digunakan dalam memilih KUA yang dijadikan sampel locus penelitian. Mengingat artikel ini ditulis ketika pendemiwabah covid-19 menyebar,menyebabkan tidak dapat mendapatkan data lapangan secara mudah.

Penelitian dengan tema pelayanan publik dan KUA sudah banyak dilakukan oleh para Peneliti dan sudah terbit dalam berbagai format, baik itu artikel ilmiah, Skripsi, Tesis bahkan Disertasi. Adapun kajian, penelitian yang terdahulu yang relevan untuk tema ini antara lain:

Muhammad Yusribau, menulis Tesis dengan judul, "Analisi Kinerja Pelayanan Publik Pada KUA Kecamatan Dullah Selatan Kota Tual 
(Studi di Bidang Peleyanan Pencatatan Nikah)" Universitas Terbuka 2013, berkesimpulan bahwa palayanan pencatatannikah di KUA yang ditelitinya masih memiliki kesenjangan gap antara harapan persepsi dan harapan pengguna layanan, meskipun demikian, secara keseluruhan penilaian masyarakat terhadap pelayanan pencatatan nikah sudah berada pada level cukup memuaskan, ada beberapa aspek pelayanan yang perlu diprioritaskan untuk ditingkatkan, meliputi, ketepatanan dan kejelasan jadwal pelayanan, kejelasan rincian biaya pelayanan nikah, penyederhanaan prosedur, kompetensi petugas dan alur pendataran nikah. Dari beberapa aspek temuan dari kajian ini, sudah ada peningkatan perbaikan pelayanan secara nasional, karena berdasarkan aturan. Seperti biaya pernikahan sudah diataur dengan jelas.

Sebuah artikel ilmiah ditulis oleh Ida Hayu Dwimawanti, dengan judul"Kualitas Pelayanan Publik (Salah Satu Parameter KeberhasilanOtonomi Daerah), berkesimpulan bahwa Kepuasan masyarakat sangat dipengaruhi oleh bagaimana cara atau perilaku petugas dalam memberikan pelayanan. Oleh karena itu aparatur pemerintah hendaknya memperhatikan dimensi-dimensi ini.

Joko Tri Haryanto menulis artikel dengan judul “, Pelayanan KUA Terhadap Persoalan Keagamaan di Kabupaten Belu Nusa Tenggara Timur," dari kajiannya dia berkesimpulan bahwa Umat Islam di wilayah yang muslim merupakan kelompok minoritas memiliki persoalan keagamaan yang berbeda dengan persoalan di wilayah mayoritas. Hal ini juga berimplikasi pada pelayanan keagamaan yang dilakukan oleh pemerintah melalui KUA

Saekhu menulis tentang, "Seputar Persoalan Pelayanan Wakaf Di Kantor Urusan Agama (KUA) Kecamatan Keling Kabupaten Jepara." Dia berkesimpulan bahwa yang menjadi faktor pengahambat perkembangan perwakafan di indonesia adalah faktor lembaga Badan Wakaf Indonesia (BWI) yang belum memiliki kantor cabang baik di tingkat provinsi atau bahkan pada tingkat kabupaten. Selain itu BWI harus berperan akatif bekerjasama dengan nazir untuk mewujudkan mencapai kemajuan yang 
dicitaa-cita bersama karena Badan Wakaf Indonesia selama ini masih belum maksimal dalam memberikan pelayanan kepada masyarakat sehingga Badan Wakaf Indonesia masih di pandang sebelah mata oleh masyarakat indonesia ini terbukti masih lemahnya pengelolaan dan pengembangan wakaf yang berbasis pada kesejahteraan masyarakat.

\section{B. Hasil dan Pembahasan}

\section{Sejarah KUA}

Sebelum berbicara jauh tentang KUA sebagai garda terdepan dalam memberikan pelayanan untuk masyarakat di bawah Kementerian Agama, alangkah baiknya, mendiskusikan bagaimana sejarah yang melatar belakangi hadirnya KUA di Indonesia.

Kantor Urusan Agama adalah instansi terkecil Kementerian Agama yang ada di tingkat Kecamatan. KUA bertugas membantu melaksanakan sebagian tugas Kantor Kementerian Agama Kabupaten di bidang urusan agama Islam di wilayah kecamatan. atau dalam Peraturan Menteri Agama (PMA) No 34 Tahun 2016, KUA merupakan Unit Pelaksana Teknis pada Kementerian Agama, berada di bawah dan bertanggung jawab kepada Direktur Jenderal Bimbingan Masyarakat Islam, KUA berlokasi di Kecamatan. Dari uraian di atas, menunjukan bagaimana posisi penting KUA sebagai Unit Pelaksana Teknis (UPT) yang ada di setiap Kecamatan.

Sementara itu, dalam sejarah hadirnya KUA dan Kementerian Agama dilatar belakangi padatahun1943PemerintahJepang di Indonesia mendirikan Kantor Shumubu (KUA) di Jakarta. Pada waktu itu yang ditunjuk sebagai Kepala Shumubu untuk wilayah Jawa dan Madura adalah KH. Hasyim Asy'ari (Pendiri Ormas Islam Nahdlatul Ulama) pendiri Pondok Pesantren Tebuireng Jombang. Sedangkan untuk pelaksanaan tugasnya, KH. Hasyim Asy'ari menyerahkan kepada puteranya K. Wahid Hasyim sampai akhir pendudukan Jepang pada bulan Agustus 1945. Setelah merdeka, Menteri Agama pertama, 
H.M.Rasjidi mengeluarkan Maklumat No. 2, tanggal 23 April 1946. Maklumatnya menyatakan bahwa semua lembaga keagamaan ditempatkan kedalam Kementerian Agama. Kelahiran Departemen Agama adalah sebuah perjuangan yang tidak bisa dipisahkan dengan dinamika perjuangan bangsa Indonesia.Pada saat bangsa ini berjuang mempertahankan kemerdekaan yang baru saja diproklamirkan, Maka lahirlah Kementerian Agama. Pembentukan Kementerian Agama tersebut selain untuk menjalankan tugasnya sebagai penanggugjawab realisasi Pembukaan UUD 1945 dan pelaksanaan pasal 29 UUD 1945, juga sebagai pengukuhan dan peningkatan status Shumubu (Kantor Urusan Agama Tingkat Pusat) pada masa penjajahan Jepang. Berdirinya Kementerian Agama disahkan berdasarkan Penetapan Pemerintah Nomor: I/SD tanggal 3 Januari 1946 bertepatan dengan 2 Muharram 1364 H. Menteri Agama pertama adalah H.M.Rasyidi, BA. Sejak itu dimulailah penataan struktur dilingkungan Kementerian Agama. Pada tahap ini, Menteri Agama H.M. Rasyidi mengambilalih beberapa tugas untuk dimasukkan dalam lingkungan Departemen Agama.

Tugas pokok Departemen Agama waktu itu ditetapkan berdasarkan Penetapan Pemerintah Nomor : 5/SD tanggal 25 Maret 1946 dan Maklumat Pemerintah Nomor 2 tanggal 24 April 1946 yang menyatakan bahwa tugas pokok Kementerian Agama adalah: menampung urusan Mahkamah Islam Tinggi yang sebelumnya menjadi wewenang Departemen Kehakiman dan menampung tugas danhak mengangkat Penghulu Landraat, Penghulu Anggota PengadilanAgama, serta Penghulu Masjid dan para pegawainya yang sebelumnya menjadi wewenang dan hak Presiden dan Bupati. Disamping pengalihan tugas di atas, MenteriAgama mengeluarkan Maklumat Menteri Agama Nomor 2 tanggal 23 April 1946 yang menyatakan, bahwa:

Pertama, instansi yang mengurus persoalan keagamaan di daerahatau SHUMUKA (tingkat Karesidenan) yang di masa pendudukan Jepang termasuk dalam kekuasaan Residen menjadi Djawatan Agama Daerah yang berada di bawah wewenang Kementerian Agama. 
Kedua, Pengangkatan Penghulu Landraat (Penghulu pada Pengadilan Agama) Ketua dan Anggota Raad (Pengadilan) Agama yang menjadi hak Residen dialihkan menjadi hak Kementerian Agama.

Ketiga,Pengangkatan Penghulu Masjid yang berada di bawah wewenang Bupati dialihkan menjadi wewenang Kementerian Agama. Sebelum maklumat Menteri Agama dilaksanakan secara efektif, kelembagaan pengurusan agama didaerah berjalan sesuai dengan keadaan dan kebutuhan. Sejak jaman penjajahan, perangkat organisasi kelembagaan yang mengurus agama yang telah tersebar ke seluruh plosok tanah air, hingga tingkat kecamatan bahkan sampai desa. Perangkat ini bekerja sebagai tenaga sukarelawan (buka pegawai negeri). Pejabat yang melayani umatIslam, khususnya yang berkaitan dengan nikah, talak, rujuk, kemasjidan/perwakafan, ditingkat Kabupaten dijabat oleh Penghulu, ditigkat Kawedanan dan Kecamatan dijabat oleh Naib Penghulu. Selanjutnya ditetapkan Peraturan Menteri Agama Nomor 188 5/K.I Tahun 1946 tanggal 20 November 1946 tentang Susunan Kementerian Agama. Pada tahap awal struktur organisasi Departemen Agama sangat sederhana yakni hanya berada di tingkat pusat yang berdiri dari 8 bagian yaitu: Bagian A (Sekertariat); Bagian B (Kepenghuluan); Bagian C (Pendidikan Agama); Bagian D (Penerangan Agama); Bagian E (Masehi Kristen); Bagian F (Masehi Katolik); Bagian G (Pegawai); Bagian H (Keuangan/Perbendaharaan). Pada tahun 1947, setelah diberlakukan Undang-undang Nomor 22 tahun 1946 tentang Pencatatan, Nikah, Talak, dan Rujuk, jabatan kepenghuluan dan kemasjidan diangkat menjadi pegawai negeri. Pejabat Raad Agama, yang semula terangkap fungsinya oleh Penghulu, setelah diberlakukanya Undang-Undang tersebut diangkat tersendiri oleh Kementerian Agama. Petugas yang mengurusi agama di Desa, khususnya dalam hal pernikahan dan kematian (yang di wilayah Jawa bisa disebut dengan modin) diterbitkan dan diatur tersediri melalui Maklumat Bersama Nomor 3 tahun 1947, tertanggal 30 April, yang ditandatangani Menteri Dalam Negeri Mr. Moh. Roem dan Menteri Agama KH. R. Fathurrahman Kafrawi. Melalui Maklumat 
tersebut para modin memiliki hak dan kewajiban berkenaan dengan peraturan masalah keagamaan di Desa, yang kedudukannya setaraf dengan pamong di tingkat pemerintah Desa. Sebagaimana pamong yang lain mereka diberi imbalan jasa berupa hak menggarap (mengelola) Tanah Bengkok Milik Desa. Sejak awal berdirinya Departemen Agama hingga tahun 1950-an, stabilitas politik belum dapat berjalan dengan baik. Pihak Belanda dan Sekutu tidak rela Indonesia merdeka. Dua kali aksi militer dilancarkan: Pertama, tanggal 21 Juli 1947 dan kedua tanggal 19 Desember 1948. Kabinet yang dibentuk Pemerintah Republik Indonesia rata-rata berumur pendek, karena silih bergantinya kabinet system parlementer. Dalam situasi perang (karena aksi militer), penataan kantor Agama di daerah jelas terganggu. Di berbagai daerah, kantor Agama berpindah-pindah, dari daerah yang di duduki Belanda kedaerah yang secara de facto masih dikuasai oleh pemerintah Republik Indonesia. Saat itu Pemerintah Agama menginstruksikan bahwa dalam 25 menghadapi perang melawan colonial Belanda, setiap aparat Kementerian Agama diharuskan turut serta berjuang mempertahankan Negara Republik Indonesia. Karena alas an itu pula, selama terjadi peperangan tersebut, pengiriman jama'ah haji sempat dihentikan. Struktur Kantor Agama (1949) diatas terus berlangsung hingga terjadi penyempurnaan struktur berdasarkan PP Nomor 33 Tahun 1949 dan PP Nomor 8 tahun 1950 tentang Susunan Organisasi Kementerian Agama. Sejak itu struktur Departemen Agama. Sejak itu struktur Departemen Agama mengalami perubahan sebagai berikut:

a. Tingkat pusat dengan susunan Organisasi sebagai berikut: 1) Menteri Agama; 2) Secretariat Jenderal yang terdiri dari: Bagian Sekertariat; Bagian Kepenghuluan; BagianPendidikan; Bagian Keuangan/Perbendaharaan;

b. Tingkat Daerah dengan susunan organisasi sebagai berikut: 1) Kantor Agama Provinsi; 2) Kantor Agama Kabupaten; 3) Kantor Kepenghuluan Kawedanan; 4) Kantor Kenaiban kecamatan. 
Berdirinya Departemen Agama Republik Indonesia, tepatnya pada tanggal 3 Januari 1946. yang tertuang dalam Penetapan Pemerintah No.1/SD tahun 1946 tentang Pembentukan Kementerian Agama, dengan tujuan Pembangunan Nasional yang merupakan pengamalan sila Ketuhanan Yang Maha Esa. Dengan demikian, agama dapat menjadi landasan moral dan etika bermasyarakat, berbangsa, dan bernegara. Dengan pemahaman dan pengamalan agama secara benar diharapkan dapat mendukung terwujudnya masyarakat Indonesia yang religius, mandiri, berkualitas sehat jasmani rohani serta tercukupi kebutuhan material dan spiritualnya. Guna mewujudkan maksud tersebut, maka di daerah dibentuk suatu Kantor Agama. Untuk di Jawa Timur sejak tahun 1948 hingga 1951, dibentuk Kantor Agama Provinsi, Kantor Agama Daerah (Tingkat Karesidenan) dan Kantor Kepenghuluan (Tingkat Kabupaten) yang merupakan perpanjangan tangan dari Kementerian Agama Pusat Bagian B, yaitu: Bidang Kepenghuluan, Kemasjidan, Wakaf dan Pengadilan Agama. Dalam perkembangan selanjutnya dengan terbitnya Keputusan Menteri Agama(KMA) Nomor 517 Tahun 2001 tentang penataan Organisasi Kantor Urusan Agama Kecamatan, maka Kantor Urusan Agama (KUA) berkedudukan di wilayah kecamatan dan bertanggung jawab kepada Kepala Kantor Departemen Agama Kabupaten/Kota yang dikoordinasi oleh Kepala Seksi Urusan Agama Islam/Bimas dan Kelembagaan Agama Islam dan dipimpin oleh seorang Kepala, yang mempunyai tugas pokok melaksanakan sebagian tugas Kantor Departemen Agama Kabupaten/Kota di bidang Urusan Agama Islam dalam wilayah Kecamatan. Dengan demikian, eksistensi KUA Kecamatan sebagai institusi Pemerintah dapat diakui keberadaanya, karena memiliki landasan hukum yang kuat dan merupakan bagian dari struktur pemerintahan di tingkat Kecamatan.

Kantor Urusan Agama (KUA) merupakan ujung tombak dari Kementerian Agama. KUA berkedudukan di Kecamatan, KUA dikomandoi oleh Kepala . Unit Pelayanan Teknis (UPT) inilah yang langsung bersentuhan dengan segenap hajat hidup umat beragama. 
maka Mereka tidak hanya terlibat dalam urusan yang terkait dengan tugas kantor, namun mereka pun harus bersiap untuk mengikuti dan melayani masyarakat dalam berbagai kegiatan keagamaan. Pelayanan KUA terhadap masyarakat ini terkait dengan peristiwa nikah, haji, zakat, dan kegiatan agama lainnya. Tak jarang dalam kegiatan yang terkait dengan tradisi masyarakat sekalipun, KUA ikut serta dan turun tangan dalam pelaksanaannya. Setidaknya memimpin doa dalam acara tersebut. Singkat kata, KUA melayani dalam segenap tetek bengek kehidupan masyarakat, dari hidup hingga mati. , berdasarkan PMA No. 34 tahun 2016, KUA mempunyai sembilan fungsi layanan kepada masyarakat.

\section{Keberagamaan di Kabupaten Pandeglang}

BPS Pandeglang menyuguhkan data terkait keberagamaan masyarakat Pandeglang sebagai berikut:

\begin{tabular}{|l|l|}
\hline Agama & $\begin{array}{l}\text { Jumlah } \\
\text { Pemeluk }\end{array}$ \\
\hline Protestan & 53 \\
\hline Katolik & 180 \\
\hline Budha & 88 \\
\hline Hindhu & 0 \\
\hline Islam & 1211588 \\
\hline Lainnya & 0 \\
\hline & \\
\hline
\end{tabular}

\section{Jumlah Penduduk dan Agama yang dianut di Kabupaten Pandeglang}

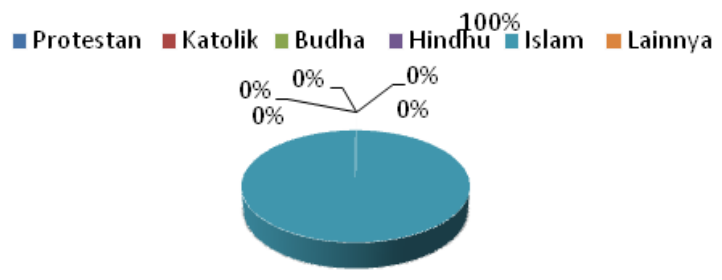

Dari data BPS Kabupaten Pandeglang di atas, dapat diketahui secara jelas bahwa umat Islam di Pandeglang menjadi umat yang mayoritas, data di atas secara tidak langsung menggambarkan bagaimana keberadaan rumah ibadah di Pandeglang selain rumah ibadah umat Islam sulit ditemukan.

Data BPS Kabupaten Pandeglang melaporkan hanya ada dua rumah ibadah non Islam, yaitu rumah ibadah bagi umat Protestan. Ada dua Gereja Protestan, masing-masing satu lain di Kecamatan Carita, dan satu di Kecamatan Labuan. Sedangkan rumah ibadah bagi umat Islam sangat 
jauh di atas rumah ibadah umat Kristen Protestan, baik itu berupa masjid Mushola, secara angka, menurut BPS Pandeglang, jumlah Mushola di Pandeglang sebanyak 1328 dan jumlah masjid secara total berjumlah 932.

Kabupaten Pandeglang terdiri dari tiga puluh lima Kecamatan, dari jumlah keseluruhan Kecamatan, hanya empat Kecamatan yang masyarakatnya heterogen, heterogen disini yang dimaksud adalah sari segi pemeluk agama, jadi dari dari, namun dalam penelitian ini tidak menjadikan semua KUA Kecamatan di Kabupaten Pandeglang sebagai locus Penelitian, mengingat waktu dan medan daerah yang sangat luas.

\section{Pengelolaan Dan Impilakasi BOP KUA}

KUA Kecamatan secaraminimal dioperasikan oleh Kepala KUA, yang bukan lain merupakan penghulu, Kecamatan Cipeucang terdiri dari sepuluh Desa, antara lain: Cikadueun, Koncang, Pasirmae, Parumasan, Kadugadung, Palanyar, Baturanjang, Kalanggunung, Curugbarang, dan Pasireurih. BOP merupakan aspek penting yang mendukung dapat dilaksanakannya layanan publik di KUA Kecamatan Cipeucang, karena bagaimana pun belanja modal yang ada di KUA itu dibiayai oleh BOP KUA, meliputi kebutuhan primer, meliputi listrik, internet, ATK dll, kebutuhan sekunder, meliputi biaya perjalanan dinas pegawai KUA, dan pemeliharaan peralatan Mesin dan yang terakhir adalah pembayaran honor Pramubakti. Ini sesuai dengan apa yang telah diatur dalam Kepdirjen Bimas Islam Nomor 283 Tahun 2019,namun dalam pengelolaan, terkait dengan waktu pencairan, besaran jumlah nominal belum terlaksana sesuai Kepdirjen di atas. Ini perlu menjadi perhatian baik dari Pegawai KUA Kecamatan Cipeucang, lebih khususnya di tataran Kementerian Agama Kabupaten Pandeglang. Secara jumlah nominal BOP yang diterima oleh KUA Kecamatan Cipeucang, jauh di bawah kebutuhan riil KUA, namun ini sangat membantu dalam mengusahakan mewujudkan pelayanan KUA yang lebih baik. Dari uraian ini bahwa, besaran BOP masih harus ditingkatkan secara nominal, dan sosialisasi Juklak Pengelolaan BOP belum sampai pada tataran KUA Kecamatan secara menyeluruh. 


\section{Kesimpulan}

Biaya Operasional Perkantoran (BOP) Kantor Urusan Agama (KUA) Kecamatan, sangat mendukung guna menghadirkan pelayanan KUA yang lebih baik, ini seyogyanya yang menjadi tujuan utama bagi tiap aparatur pemberi layanan publik.

Pendanaan yang berasal dari pemerintah Pusat/APBN, sebagaian besar layanan KUA terbantu dengan pendanaan ini, meskipun, tidak dapat dipungkiri bahwa BOP KUA belum sepenuhnya dapat menggerakan KUA untuk memberikan pelayanan secara maksimal dan optimal. Masih ada beberapa layanan yang belum terbantu dengan adanya dana BOP. Selain itu ditemukan bahwa sosialisasi tentang Juklak pengelolaan BOP KUA harus lebih masif dan harusnya ada pembinaan yang lebih intensif agar KUA dalam melakukan pengelolaan lebih mengikuti atau mentaati juklak yang berlaku. 


\section{Daftar Pustaka}

Asyakir, Muhammad. Dan Zaili Rusli, “Analisis Pelaksanaan Tugas pokok dan Fungsi (TUPOKSI) Kantor Urusan Agama (KUA) Kecamatan Mandau dalam Melaksanakan Pelayanan dan Bimbingan Kepada Masyarakat.

Bungin,Burhan.Metode Penelitian Kuantitatif. Jakarta: Kencana Prenada Media Group, 2006.

DepartemenAgamaRI,BukuRencanaIndukKUADanPengembangannya, Jakara, Ditjen Bimas Islam dan Urusan Haji, 2002.

Hayu Dwimawanti,Ida. "Kualitas Pelayanan Publik (Salah Satu Parameter Keberhasilan Otonomi Daerah)," dalam Dialogue JIAKP, Vol.1, No.1, Januari 2004.

Feener,R. Michael. “Review "Kyai Haji Abdul Wahid Hasyim: His Contribution to Muslim Educational Reform and Indonesian Nastionalism During the Twentieth Century Karya Achmad Zaini" dalam Middle East Studies Association Bulletin, Vol. 33, No. 1, Summer 1999.

PMA No. 36 Tahun 2016.

Saekhu, "Seputar Persoalan Pelayanan Wakaf Di Kantor Urusan Agama (KUA) Kecamatan Keling Kabupaten Jepara."Dalam Economica Vol. V, Edisi 2, Oktober 2014.

Sugiarto, Agus. Peran KUA dalam mengimplementasikan undangundang nomer 1 tahun 1974 tentang perkawinan di Kecamatan Tanjung Bintang Kabupaten Lampung Selatan:Study tentang Manajemen Dakwah, Tesis UIN Raden Intan Lampung, 2017.

Syamsurijal,"Dialektika Regulasi dan Tradisi dalam Pelayanan

Perkawinan di Kua," dalam Jurnal SMaRT Volume 03 Nomor 02 Desember 2017. 
Timur Penulis Depag RI, Tugas-Tugas Pejabat Pencatat Nikah, Bimbingan

Masyarakat Islam danPenyelenggaraan Haji Departemen Agama RI, Jakarta, 2004.

Tim BPS Pandeglang, Kabupaten Pandeglang dalam Angka: Penyediaan Data untuk Persiapan Pembangunan, Pandeglang: Rajawali, 2020

Tri Haryanto, Joko. “, Pelayanan Kua Terhadap Persoalan Keagamaan Di Kabupaten Belu Nusa Tenggara Timur,"dalam Jurnal "Analisa" Volume XVIII, No. 02, Juli - Desember 2011.

Yusribau, Muhammad."Analisi Kinerja Pelayanan Publik Pada KUA Kecamatan Dullah Selatan Kota Tual (Studi di Bidang Peleyanan Pencatatan Nikah)" Universitas Terbuka 2013. 


\section{Endnotes}

1. Ida Hayu Dwimawanti, "Kualitas Pelayanan Publik (Salah Satu Parameter Keberhasilan Otonomi Daerah)," dalam Dialogue JIAKP, Vol.1, No.1, Januari 2004, 113.

2. Muhammad Asyakir Dan Zaili Rusli, "Analisis Pelaksanaan Tugas pokok dan Fungsi (TUPOKSI) Kantor Urusan Agama (KUA) Kecamatan Mandau dalam Melaksanakan Pelayanan dan Bimbingan Kepada Masyarakat," 1.

3. Burhan Bungin, Metode Penelitian Kuantitatif. Jakarta: Kencana Prenada Media Group, 2006), 47.

4. Muhammad Yusribau, menulis Tesis dengan judul, "Analisi Kinerja Pelayanan Publik Pada KUA Kecamatan Dullah Selatan Kota Tual (Studi di Bidang Peleyanan Pencatatan Nikah)" Universitas Terbuka 2013, II.

5. Ida Hayu Dwimawanti, dengan judul"Kualitas Pelayanan Publik (Salah Satu Parameter Keberhasilan Otonomi Daerah) dalam Dialogue॰ JIAKP, Vol.1, No.1, Januari 2004, 114.

6. Joko Tri Haryanto menulis artikel dengan judul “, Pelayanan Kua Terhadap Persoalan Keagamaan Di Kabupaten Belu Nusa Tenggara Timur,"dalam Jurnal “Analisa” Volume XVIII, No. 02, Juli - Desember 2011, 260.

7. Saekhu menulis tentang, "Seputar Persoalan Pelayanan Wakaf Di Kantor Urusan Agama (KUA) Kecamatan Keling Kabupaten Jepara."dalam Economica Vol. V, Edisi 2, Oktober 2014, 46.

8. Depag RI, Tugas-Tugas Pejabat PencatatNikah,BimbinganMasyarakat Islam danPenyelenggaraan Haji,(Departemen Agama RI, Jakarta, 2004), 12.

9. Lihat: PMA No. 34 Tahun 2016.

10. Wahid Hasyim adalah figur penting dalam mengembangkan Nahdlatul Ulama, dia adalah salah satu sosok yang menandatangani piagam Jakarta, dan di kemudian dia hari menjadi Menteri Agama. Lihat:R. Michael Feener, "Review "Kyai Haji Abdul Wahid Hasyim: His Contribution to Muslim Educational Reform and Indonesian Nastionalism During the Twentieth 
Century Karya Achmad Zaini" dalam Middle East Studies Association Bulletin, Vol. 33, No. 1 (Summer 1999), 86. Hasyim yang juga merupakan Bapak dari Presiden Republik Indonesia ke empat, KH. Abdurrahman Wahid atau lebih dikenal dengan sebutan Gus Dur.

11. Departemen Agana RI, Buku Rencana Induk KUA Dan Pengembangannya, (Jakarta, Ditjen Bimas Islam dan Urusan Haji, 2002), 5.

12. Lihat juga: Agus Sugiarto, (Peran KUA dalam mengimplementasikan undang-undang nomer 1 tahun 1974 tentang perkawinan di Kecamatan Tanjung Bintang Kabupaten Lampung Selatan:Study tentang Manajemen Dakwah, Tesis UIN Raden Intan Lampung, 2017), 21.

13. Lihat PMA No. 36 Tahun 2016.

14. Berdasarkan PMA No. 34 tahun 2016, KUA memiliki tugas pokok fungsi, antara lain:

a. Pelaksanaan Pelayanan Pengawasan, pengawasan, pencatatan, nikah, dan rujuk

b. penyusunan statistik layanan dan bimbingan masyarakat Islam

c. pengelolaan dokumentasi dan sistem informasi manajemen KUA

d. pelayanan bimbingan keluarga sakinah

e. pelayanan bimbingan kemasjidan

f. pelayanan bimbingan hisab rukyat dan pembinaan syariah

g. pelayanan bimbingan dan penerangan Agama Islam

h. pelayanan bimbingan zakat dan wakaf

i. pelaksanaan ketatausahaan dan kerumahtanggan KUA Kecamatan

15. Syamsurijal, "Dialektika Regulasi dan Tradisi dalam Pelayanan Perkawinan di Kua," dalam Jurnal SMaRT Volume 03 Nomor 02 Desember 2017, 126.

16. Tim BPS Pandeglang, Kabupaten Pandeglang dalam Angka: Penyediaan Data untuk Persiapan Pembangunan, (Pandeglang: Rajawali, 2020),97.

17. Wawancara Pegawai KUA Kecamatan Cipeucang, pada 30 Maret 2020. 